\title{
Афффинные взаимодействия на поверхности пьезоэлектрического сенсора, модифицированного углеродными нанотрубками, при определении фторхинолонов
}

\author{
Шукшина Е.И. ${ }^{1}$, Фарафонова О.В. ${ }^{1}$, Шанин И.А. ${ }^{3}$, Гражулене С.С. ${ }^{2}$, \\ Еремин С.А. ${ }^{3}$, Ермолаева Т.Н. ${ }^{1}$ \\ ${ }^{1}$ Липецький государственный технический университет, Липеияк \\ ${ }^{2}$ Институт проблем технологии микроэлектроники и особо чистых материалов РАН, Черниголовка \\ ${ }^{3}$ Московский государственный университет им. М.В. Ломоносова, Москва
}

Поступила в редакцию 17.02.2018 г.

DOI: https://doi.org/10.17308/sorpchrom.2018.18/544

Изучены условия получения распознающего слоя пьезоэлектрического сенсора на основе многостенных углеродных нанотрубок (УНТ) для высокочувствительного определения фторхинолонов в прямом и конкурентном форматах иммуноанализа. Установлено, что использование на стадии иммобилизации УНТ способствует увеличению присоединенной массы и концентрационной чувствительности сенсора, вследствие возникновения 3D граничного слоя, повышающего связывающую способность поверхности электрода, и, следовательно, эффективности аффинных взаимодействий для анализируемых фторхинолонов. Показано, что применение УНТ при формировании распознающего слоя расширяет диапазон определяемых содержаний фторхинолонов в конкурентном (10-350 и 10-370 нг/см³ для левофлоксацина и ципрофлоксацина) и прямом форматах

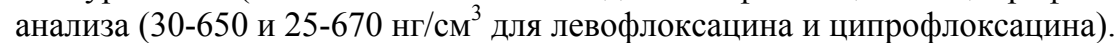

Ключевые слова: аффинные взаимодействия, пьезоэлектрический иммуносенсор, многостенные углеродные нанотрубки, конкурентный формат иммуноанализа, прямой формат иммуноанализа, левофлоксацин, ципрофлоксацин.

\section{Affine interactions on the surface of a piezoelectric sensor modified by carbon nanotubes in the determination of fluoroquinolones}

\author{
Shukshina E.I. ${ }^{1}$, Farafonova O.V. ${ }^{1}$, Grazhulene S.S. ${ }^{2}$, \\ Eremin S.A. ${ }^{3}$, Ermolaeva T.N. ${ }^{1}$ \\ ${ }^{1}$ Lipetsk State Technical University, Lipetsk \\ ${ }^{2}$ Institute of Microelectronics and High Purity Materials, RAS technology, Chernogolovka \\ ${ }^{3}$ M.V. Lomonosov Moscow State University, Moscow
}

Affine interactions on the surface of a piezoelectric immunosensor modified with carbon nanotubes were studied in the determination of ciprofloxacin and levofloxacin in direct and competitive assay formats. An increase in the specific surface of the sensor was shown when multi-walled carbon nanotubes are used due to the appearance of a 3D boundary layer with high porosity, which is confirmed by the growth of the mass of the recognition layer and the concentration sensitivity. Optimal concentrations of the hapten protein conjugate $\left(0.5 \mu \mathrm{l} / \mathrm{cm}^{3}\right)$ and antibodies to fluoroquinolones were determined in the direct assay (dilution of 
antibodies 14/86 and 10/90 for levofloxacin and ciprofloxacin) in competitive assay formats (15/85 for levofloxacin and 18 / 82 for ciprofloxacin). Operational characteristics are substantiated: the contact time of the sensor with the analyzed sample $(20 \mathrm{~min})$, the flow rate of the carrier solution $(30 \mu \mathrm{l} / \mathrm{min}$ and $50 \mu \mathrm{l} / \mathrm{min})$, depending on the method of creating the recognition layer. Methods for the determination of fluoroquinolones in flow-injection and static regimes were developed. Was shown that the use of CNTs helps to expand the range of detectable fluoroquinolones content in competitive 10-350 and 10-370 $\mathrm{ng} / \mathrm{cm}^{3}$ and direct analysis formats of $30-650$ and $25-670 \mathrm{ng} / \mathrm{cm}^{3}$ for levofloxacin and ciprofloxacin, respectively. The correctness of the determination of fluoroquinolones was evaluated by the "added-found" method. The values of the relative standard deviation $\mathrm{s}_{\mathrm{r}}$ indicate a high reproducibility of the measurement results $\left(\mathrm{s}_{\mathrm{r}}\right.$ does not exceed 0.08$)$. The methods were tested in the analysis of levofloxacin and ciprofloxacin in milk.

Keywords: affinity interactions, piezoelectric immunosensor, multi-walled carbon nanotubes, competitive immunoassay format, direct immunoassay format, levofloxacin, ciprofloxacin.

\section{Введение}

Фторхинолоны (ФХ) получили широкое распространение в качестве антибактериальных средства для лечения и профилактики заболеваний крупного рогатого скота и птицы [1]. Поэтому их остаточные содержания обнаруживаются в молоке, яйцах, мясе и представляют опасность для человека, поскольку могут быть причиной изменению микрофлоры, появления аллергических реакций и дисбактериоза. В РФ установлены максимально допустимые содержания фторхинолонов на уровне 100300 мкг/кг - в мясе и почках, 100 мкг/кг - в молоке.

Наиболее часто для определения остаточного содержания фторхинолоновых антибиотиков в продукции животноводства используется метод ВЭЖХ [2-3]. Применение флуориметрического детектора обеспечивает определение фторхинолонов

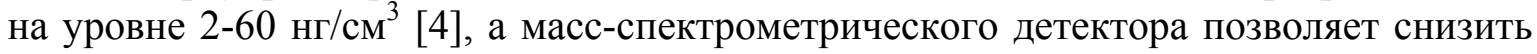
предел обнаружения ряда соединений (ципрофлоксацин, данофлоксацин, энрофлоксацин и сарафлоксацин) до 0.2 нг/г [5]. Однако такие методы требуют применения дорогостоящего оборудования и высококвалифицированного обслуживающего персонала, а также достаточно сложной пробоподготовки, что ограничивает их применение для рутинного анализа.

Альтернативой хроматографическим методам определения фторхинолонов выступают иммунохимические методы анализа, характеризующиеся относительной простотой выполнения и высокой селективностью. Среди иммунохимических методов следует выделить иммуноферментный метод анализа [6-9], а также метод поляризационного флуоресцентного иммуноанализа [10].

Кроме того, значительное внимание уделяется разработке иммуносенсоров, позволяющих осуществлять определение фторхинолонов практически без предварительной подготовки пробы. Наиболее часто применяются электрохимические иммуносенсоры [11-12], требующие использования специальных меток (ферментных, флуоресцентных). В то же время, описаны безметочные импедиметрические имму-

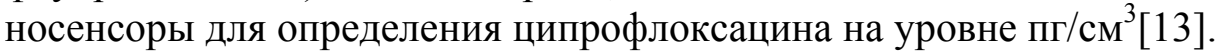

Пьезоэлектрические иммуносенсоры для определения фторхинолонов ранее не применялись. В качестве аналитического сигнала пьезоэлектрического сенсора выступает изменение частоты его колебаний при образовании аффинного комплекса антиген/антитело. По чувствительности пьезоэлектрические сенсоры сопоставимы, а в некоторых случаях даже превосходят широко используемые в анализе оптические, спектрофотометрические, флуоресцентные и электрохимические сенсоры [14-15]. Поэтому актуально их более широкое применение в анализе, в том числе при определении в пищевых продуктах и биологических средах следовых концентраций лекарственных препаратов. 
Для усиления аналитического сигнала пьезоэлектрического гравиметрического иммуносенсора используются два подхода - увеличение концентрации «сайтов» распознавания на поверхности его электрода, например, за счет использования многостенных углеродных нанотрубок [16], и утяжеление присоединяемых в ходе анализа молекул аналита с помощью наночастиц золота или вторичных антител [17].

Цель настоящего исследования - изучение аффинных реакций, протекающих на поверхности пьезоэлектрического иммуносенсора, модифицированного углеродными нанотрубками, при определении фторхинолонов ципрофлоксацина и левофлоксацина в прямом и конкурентном формате анализа, разработка методики определения следовых концентраций ФХ в пищевых продуктах.

\section{Эксперимент}

Объекты исследования. Фторхинолоны: ципрофлоксацин (Сір) и левофлоксацин (Lev) (SigmaAldrich Corporation, США) для иммунохимического определения которых применяли поликлональные (Ab:Lev; Ab:Cip) антитела, полученные ранее по методике [7] и предоставленные Ереминым С.A.

В работе использовали следующие реактивы: этанол, ацетон («Quimica», Ис-

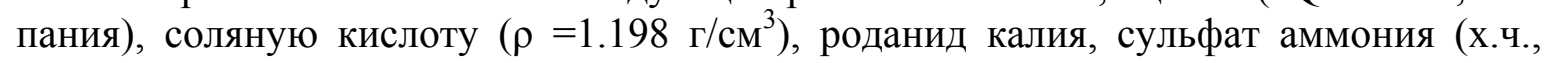
«Реахим», Россия), диметилформамид (DMF), (х.ч. «Merck», Германия), 2-амино-3меркаптопропионовую кислоту (цистеин) («Sigma», США), глутаровый альдегид (GA), N-гидроксисукцинимид (NHS), N-этил-N'-(3-диметиламинопропил) карбодиимид гидрохлорид (EDAC) («Reanal», Венгрия), бычий сывороточный альбумин (BSA) («ПанЭко», Россия).

Многостенные углеродные нанотрубки получены в Институте проблем технологии микроэлектроники и особо чистых материалов РАН, (Черниголовка) методом каталитического пиролиза паров этанола при 400-550․ В качестве предкатализатора применялся нитрат никеля, который непосредственно перед осаждением УНТ термически разлагали до металла. При каталитическом разложении паров этанола УНТ осаждались на поверхности катализатора (никеля), который после синтеза отмывали кислотами. После отмывки катализатора образцы промывали дважды деионизированной водой, высушивали, просеивали через сито [18].

Активация многостенных углеродных нанотрубок осуществлялась по методике, описанной ранее [16] с использованием ультразвуковой ванны («ПСБ-Галас», Россия). Фосфатный физиологический буферный раствор (PBS) (pH=7.2) готовили растворением в 1 дм $^{3}$ бидистиллированной воды 8.0145 г $\mathrm{NaCl}, 0.2012$ г KCl, 2.864 г $\mathrm{NaH}_{2} \mathrm{PO}_{4} \cdot 12 \mathrm{H}_{2} \mathrm{O}, 0.204$ г $\mathrm{KH}_{2} \mathrm{PO}_{4}$.

Гаптен-белковые конъюгаты (Lev-BSA, Cip-BSA) синтезировали методом карбодиимидной конденсации: к раствору 5 мг BSA (0.07 мкмоль) в $2.5 \mathrm{~cm}^{3}$ дистиллированной воды прибавляли 2 мг ципрофлоксацина (6 мкмоль) или 2.2 мг левофлоксацина (6 мкмоль) и 30 мг EDAC (156 мкмоль). Реакционную массу выдерживали 4 часа при комнатной температуре, а затем 16 часов при $4^{\circ} \mathrm{C}$. Очистку осуществляли путём диализа против $0.2 \%$ раствора $\mathrm{NaCl}$ в воде в течение 4 дней, периодически меняя раствор.

В качестве физического преобразователя сенсора использовали пьезокварцевые резонаторы АТ-среза с собственной частотой колебаний 10 МГц \pm 1 Гц с золотыми электродами (диаметр 4 мм) (ЗАО «ЭТНА», Россия). Аналитический сигнал сенсора регистрировали в статическом режиме на приборе QCM10M3CH (3АО «ЭТНА», Россия) и в проточно-инжекционном режиме на установке, описанной ранее [19], состоящей из проточной ячейки объемом 15-20 мкл, обеспечивающей контакт с

Шукшина и др. / Сорбционные и хроматографические процессы. 2018. Т. 18. № 3 
анализируемой пробой только одной стороны сенсора, перистальтического насоса («KNAUER», Германия), цифрового модуля ДиСкоп («Бафика», Россия) и персонального компьютера.

Формирование распознающего слоя сенсора осуществляли следующими способами.

Способ 1. На поверхность электрода резонатора, обезжиренного этанолом, с помощью микрошприца наносили 2 мкл этанольного раствора цистеина $(1 \mathrm{MM})$, выдерживали 90 мин при комнатной температуре, затем 5 мкл 5\% раствора GA, спустя 15-20 мин сенсор промывали PBS и наносили 5 мкл $0.05 \%$-го раствора гептенбелкового конъюгата. Иммуносенсор помещали во влажную камеру и выдерживали $10-12$ ч при $4^{\circ} \mathrm{C}$.

При формировании распознающего слоя на основе УНТ вначале осуществляли модификацию поверхности электрода цистеином, затем дозировали на цистеиновую подложку 2 мкл коллоидного раствора УНТ (100 мг/дм³ ${ }^{3}$, выдерживали в течение 24 ч при $4^{\circ} \mathrm{C}$, активировали карбоксильные группы на поверхности УНТ с помощью растворов EDAC и NHS (наносили 2 мкл смеси: 5 мг EDAC и 5 мг NHS в 200 мкл DMF), выдерживали 90 мин и проводили иммобилизацию гаптен-белковых конъюгатов (пособ 2) или антител к фторхинолонам (поо 3 ).

Определение фторхинолонов осуществляли в статическом и проточноинжекционном режимах. В статическом режиме на поверхность сенсора с иммобилизованными гаптен-белковыми конъюгатами (способ 1,2$)$ или антителами к фторхинолонам (способ 3) дозировали 5 мкл предварительно подготовленного анализируемого раствора, через 5 мин промывали поверхность сенсора от несвязавшихся реагентов PBS ( $\mathrm{pH}=7.2)$, высушивали до постоянной массы и измеряли аналитический сигнал на воздухе.

Проточно-инжекционное определение фторхинолонов осуществляли в конкурентном формате анализа, регистрируя снижение частоты колебаний сенсора $(\Delta \mathrm{f})$ при образовании иммунокомплекса между гаптен-белковым конъюгатом, иммобилизованным на поверхности электрода (способ 2), и антителами к форхинолонам, несвязавшимися с определяемым соединением в пробе.

После измерения аналитического сигнала осуществляли регенерацию биослоя, пропуская над поверхностью сенсора регенерирующий раствор или дозируя на поверхность сенсора 200 мкл 0.003 М раствор KCNS, способствующий диссоциации

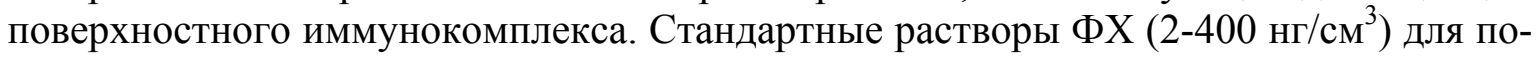
строения градуировочного графика получали растворением фторхинолов в бидистиллированной воде.

Пробоподготовка молока. $10 \mathrm{~cm}^{3}$ пробы (молоко, разбавленное в 3 раза) добавляли $5 \mathrm{~cm}^{3}$ этанола для гидролиза жиров и вводили $2 \mathrm{~cm}^{3}$ сульфата аммония. Ocaдок отделяли центрифугированием (3 мин, 7000 об/мин) (центрифуга «МPW», Польша). Для анализа использовалась надосадочная жидкость.

\section{Обсуждение результатов}

Как правило, для определения низкомолекулярных соединений с помощью пьезоэлектрического иммуносенсора используется конкурентный формат иммуноанализа, позволяющий косвенно определять концентрацию аналита по количеству антител, связавшихся с гаптен-белковым конъюгатом, иммобилизованным на поверхности сенсора [20]. Прямой формат иммуноанализа для определения низкомолекулярных соединений, как правило, не применяется. Однако, увеличение удельной поверхности сенсора при применении многостенных углеродных нанотрубок за счет

Шукиина и др. / Сорбционные и хроматографические процессы. 2018. Т. 18. № 3 
возникновения 3D граничного слоя с высокой пористостью, создает предпосылки для определения низкомолекулярных соединений в прямом формате анализа, что было продемонстрировано ранее на примере определения рактопамина [16].

Рассмотрена возможность применения пьезоэлектрического аффинного сенсора для определения ципрофлоксацина и левофлоксацина в конкурентном и прямом форматах анализа при регистрации сигнала в статическом и проточноинжекционном режиме.

Изучены условия формирования распознающего слоя сенсора (рис. 1). Для оценки качества слоя применяли метод пьезокварцевого микровзвешивания, позволяющий по уравнению $\Delta \mathrm{f}=\mathrm{k} \cdot \Delta \mathrm{m}$ определить массу слоя $\left(\Delta \mathrm{m}_{\text {пл }}\right.$, мкг $)$ и рассчитать концентрационную чувствительности сенсора $\left(\mathrm{S}_{\mathrm{c}}, \Gamma_{\llcorner} \cdot \mathrm{cm}^{3} \cdot{ }^{3} \Gamma^{-1}\right)$, характеризующую эффективность аффинной реакции на поверхности электрода, и устойчивость биослоя $(\mathrm{N})$, показывающую число циклов распознавания без существенного изменения аналитического сигнала, табл. 1. Устойчивость биослоя в существенной степени зависит от применяемого модификатора поверхности и прочности связей, образующихся в процессе его формирования. Экспериментальные исследования показали практически одинаковую устойчивость распознающего слоя, сформированного различными способами (26-28 циклов), что связано с применением цистеина, обеспечивающего высокую адгезию к поверхности золотого электрода.

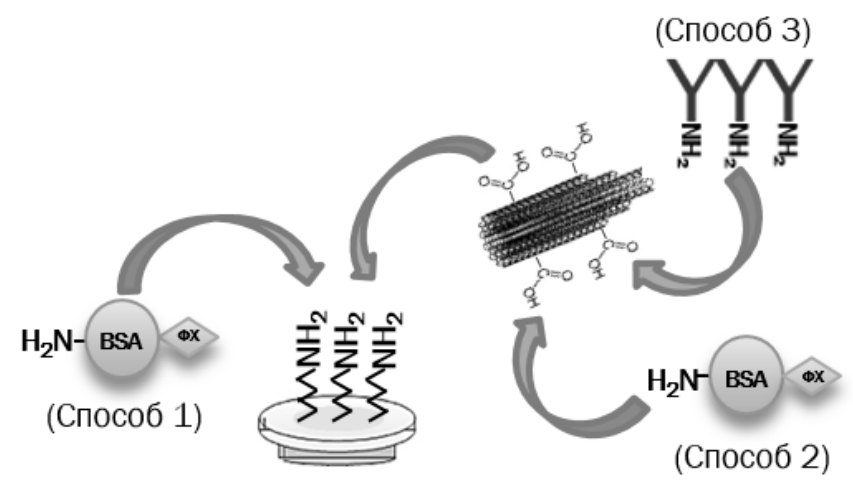

Рис. 1. Схема формирования распознающего слоя

Для получения сопоставимых характеристик сенсоров с распознающим слоем, сформированным способами 1-3, предварительно экспериментальным путем выбраны концентрации гаптен-белковых конъюгатов и антител к фторхинолонам, используемых на стадии иммобилизации или при выполнении анализа в конкурентном формате.

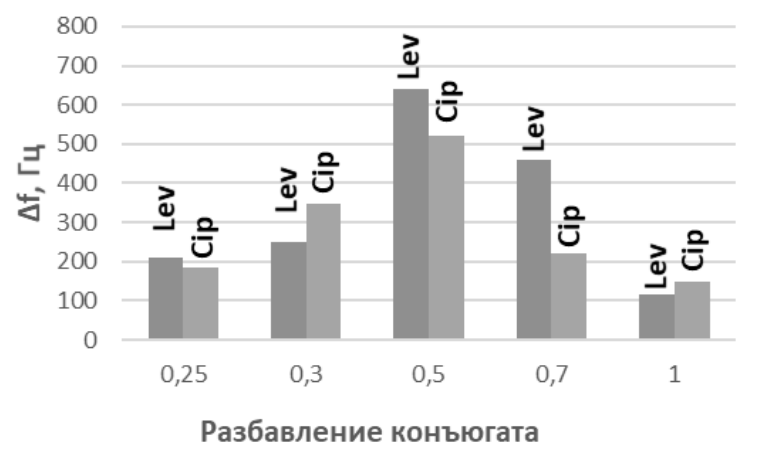

Рис. 2. Определение концентрации конъюгатов

Оптимальные концентрации гаптен-белкового конъюгата устанавливали на основе зависимости аналитического сигнала сенсора от концентрации конъюгата в 
интервале (мкл/см ${ }^{3}$ ) 0.25-1.00. Максимальный аналитический сигнал сенсора, как для Lev, так и для Cip отмечается при применении раствора конъюгата с концентрацией 0.5 мкл/ $\mathrm{cm}^{3}$ (рис. 2).

Определение оптимальной концентрации антител к фторхинолонам, используемых в конкурентном и прямом формате анализа, осуществляли на основе зависимости аналитического сигнала сенсора от степени разбавления поликлональных антител (рис. 3-4). Концентрация антител в конкурентном формате отвечает 50\%-ному связыванию, что позволяет достичь оптимального соотношения активных центров на поверхности сенсора и количества молекул антител, не связавшихся в гомогенный аффинный комплекс с фторхинолонами (степень разбавления антител 14/86 и 10/90 для левофлоксацина и ципрофлоксацина, соответственно) (рис. 3). А в прямом формате анализа оптимальная концентрация антител отвечает максимуму на графике (рис. 4), соответствующему насыщению распознающего слоя (15/85 для левофлоксацина и 18/82 для ципрофлоксацина).

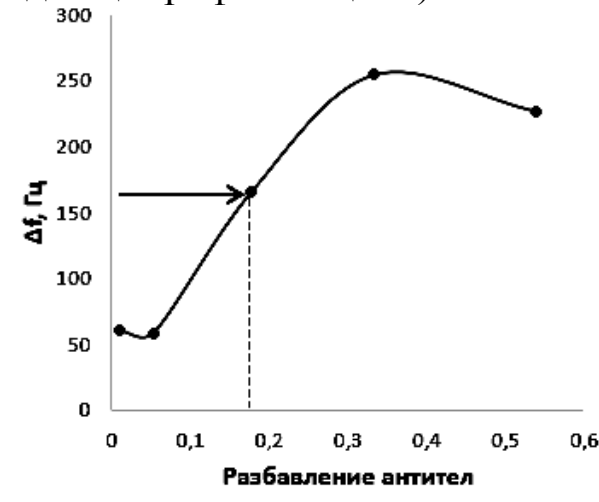

a

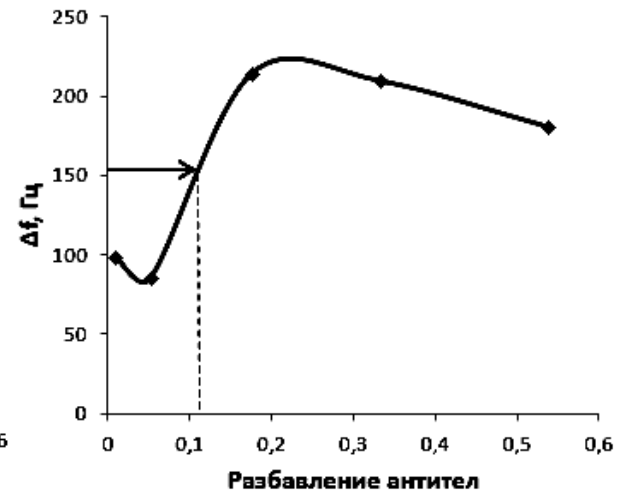

б

Рис. 3. Определение концентрации поликлональных антител, отвечающей 50\%-ному связыванию: к $\operatorname{Lev}(\mathrm{a})$ и $\mathrm{Cip}(б)$

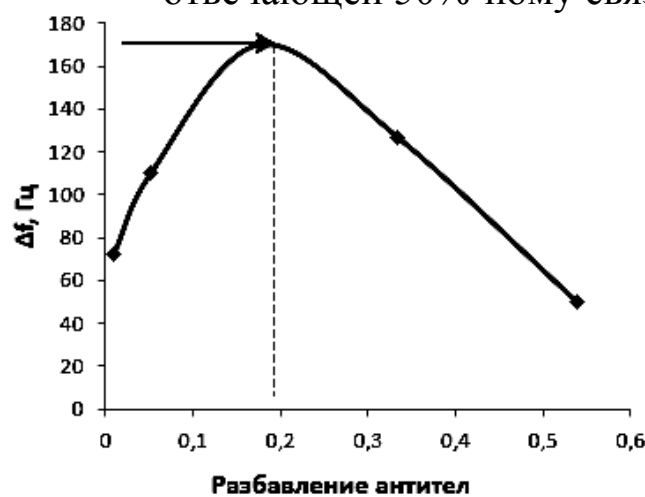

a

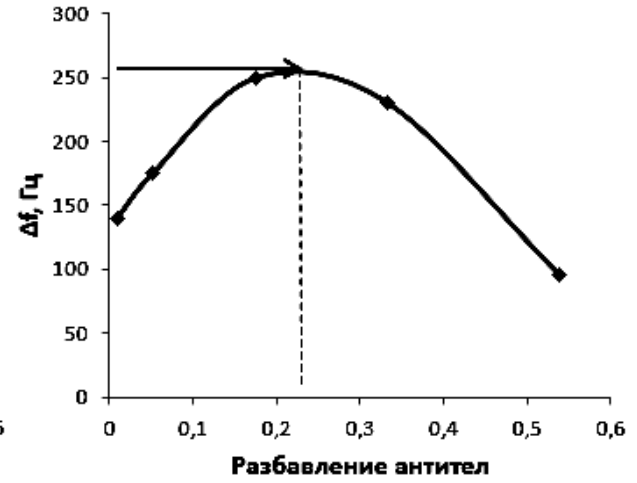

6

Рис. 4. Определение концентрации поликлональных антител для прямого формата: к Lev (а) и Cip (б)

Сопоставление значений $\Delta \mathrm{m}_{\text {пл }}$ и $\mathrm{S}_{\mathrm{c}}$ для сенсоров с распознающим слоем, полученным способами 1 и 2, показало, что использование на стадии иммобилизации углеродных нанатрубок способствует увеличению присоединенной массы и концентрационной чувствительности сенсора и, следовательно, эффективности аффинных взаимодействий для обоих фторхинолонов. Применение углеродных нанотрубок при формировании распознающего слоя на основе антител (табл. 1), демонстрирует достаточно высокие значения $\mathrm{S}_{\mathfrak{c}}$, сопоставимые с аналогичными величинами для покрытия, полученного способом 2, что свидетельствует о возможности определения фторхинолонов с помощью пьезоэлектрического сенсора в прямом формате имму- 
ноанализа. Сорбционные слои, сформированные способами 2 и 3, проявляют практически одинаковую устойчивость и близкое значение массы биослоя.

Таблица 1. Влияние способа иммобилизации на характеристики пьезоэлектрического иммуносенсора (в статических условиях)

\begin{tabular}{|c|c|c|c|c|}
\hline $\begin{array}{c}\text { Способ формирования распо- } \\
\text { знающего слоя }\end{array}$ & Фторхинолон & $\Delta \mathrm{m}_{\text {пл, мкг }}$ & $\begin{array}{c}\mathrm{S}_{\mathrm{c}}, \\
\Gamma_{ц} \cdot \mathrm{cm}^{3} \cdot \mathrm{м \kappa г}^{-1}\end{array}$ & $\mathrm{~N}$ \\
\hline \multirow{2}{*}{1} & Левофлоксацин & 33.50 & 670.0 & 26 \\
\cline { 2 - 5 } & Ципрофлоксацин & 32.98 & 659.6 & 26 \\
\hline \multirow{2}{*}{2} & Левофлоксацин & 64.63 & 1313.4 & 28 \\
\cline { 2 - 5 } & Ципрофлоксацин & 64.35 & 1307.7 & 27 \\
\hline \multirow{2}{*}{3} & Левофлоксацин & 62.15 & 1263.0 & 28 \\
\cline { 2 - 5 } & Ципрофлоксацин & 61.94 & 1258.7 & 27 \\
\hline
\end{tabular}

Величина аналитического сигнала пьезоэлектрического сенсора зависит от способа его регистрации. Так, при измерении сигнала в статических условиях его величина зависит от времени контакта сенсора с анализируемой пробой, которое устанавливается заранее (20 мин). В то же время при проведении измерений в проточно-инжекционном режиме, позволяющем сократить продолжительность анализа, важное значение имеет выбор оптимальной скорости потока раствора носителя, в качестве которого применяли раствор PBS.

Исследование влияния скорости потока раствора-носителя (1-120 мкл/мин) на величину аналитического сигнала сенсора показало, что максимальное значение $\Delta \mathrm{f}$ при определении фторхинолонов в конкурентном формате иммуноанализа достигается при скорости 30 мкл/мин (на распознающем слое, сформированном способом 1) и 50 мкл/мин (на распознающем слое, полученном способом 2), (рис.5). Возможность проведения измерений с более высокой скоростью потока раствора носителя при использовании биослоя на УНТ, свидетельствует как о более высокой концентрации поверхностных «сайтов» распознавания, так и о стерической доступности иммобилизованных гаптен-белковых конъюгатов для взаимодействия с антителами. Оптимальная скорость потока раствора-носителя одинакова для левофлоксацина и ципрофлоксацина, т.е. не зависит от строения, определяемого фторхинолона.

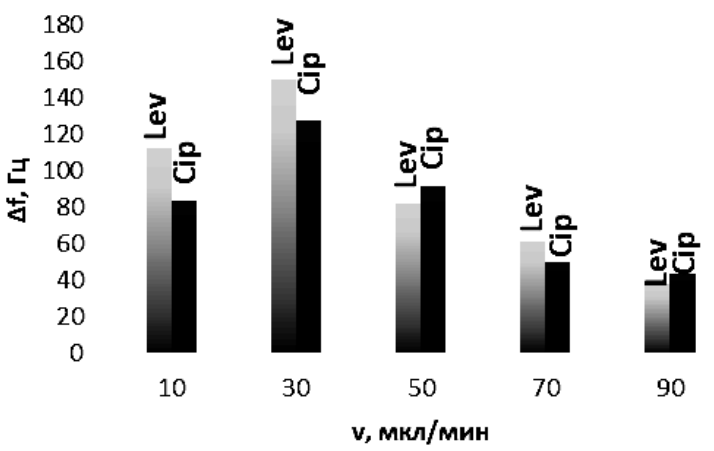

a

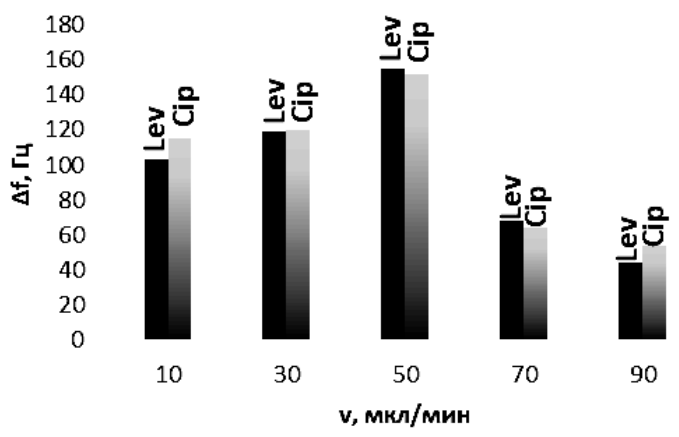

6

Рис. 5. Влияние скорости потока на величину аналитического сигнала сенсора: способ 1 (а); способ 2 (б)

Разработаны методики определения фторхинолонов в проточноинжекционном и статическом режимах с применением распознающего слоя, полученного различными способами. Метрологические характеристики, приведенные в таблице 2 , показывают, что минимальное значение предела обнаружения $\mathrm{C}_{\min }$ достигается при применении сенсора, модифицированного только цистеином, а использо- 
вание УНТ способствует расширению диапазона определяемых содержаний левофлоксацина и ципрофлоксацина в конкурентном и прямом форматах анализа.

Таблица 2. Метрологические характеристики определения фторхинолонов

\begin{tabular}{|c|c|c|c|c|c|}
\hline $\begin{array}{c}\text { Способ формирова- } \\
\text { ния распознающего } \\
\text { слоя }\end{array}$ & $\Phi X$ & $\begin{array}{l}\mathrm{C}_{\min }, \\
\mathrm{H \Gamma} / \mathrm{cm}^{3}\end{array}$ & $\begin{array}{c}\text { Диапазон опреде- } \\
\text { ляемых содержа- } \\
\text { ний, нг/см }\end{array}$ & $\begin{array}{c}\text { Уравнение градуиро- } \\
\text { вочного графика }\end{array}$ & $\mathrm{R}^{2}$ \\
\hline \multicolumn{6}{|c|}{ Статический режим } \\
\hline \multirow{2}{*}{ Способ 1} & Lev & 3 & $10-100$ & $y=-0.98 x+654$ & 0.95 \\
\hline & Cip & 4 & $5-80$ & $y=-2.9 x+950$ & 0.95 \\
\hline \multirow{2}{*}{ Способ 2} & Lev & 9 & $10-350$ & $y=-2.76 x+1065$ & 0.96 \\
\hline & Cip & 8 & $10-370$ & $y=-2.78 x+1181$ & 0.96 \\
\hline \multirow{2}{*}{ Способ 3} & Lev & 25 & $30-650$ & $\mathrm{y}=1.47 \mathrm{x}+279$ & 0.97 \\
\hline & Cip & 21 & $25-670$ & $y=1.72 x+248$ & 0.98 \\
\hline \multicolumn{6}{|c|}{ Проточно-инжекционный режим } \\
\hline \multirow{2}{*}{ Способ 2} & Lev & 9 & $30-450$ & $y=-2.29 x+1179$ & 0.94 \\
\hline & Cip & 9 & $40-490$ & $y=-2.15 x+1148$ & 0.93 \\
\hline
\end{tabular}

Правильность определения левофлоксацина и ципрофлоксацина оценена методом «введено-найдено» при анализе молока. Сопоставление табличных и рассчитанных коэффициентов Стьюдента не выявило значимых различий между введенными и найденными концентрациями фторхинолонов (табл. 3).

Таблица 3. Результаты определения фторхинолонов в молоке методом «введенонайдено» $(\mathrm{P}=0.95, \mathrm{n}=3)$

\begin{tabular}{|c|c|c|c|c|}
\hline Фторхинолон & Введено, нг/ см ${ }^{3}$ & Найдено, нг/ см ${ }^{3}$ & $\begin{array}{c}\text { Процент от- } \\
\text { крытия, \% }\end{array}$ & $\mathrm{S}_{\mathrm{r}}$ \\
\hline \multicolumn{5}{|c|}{ Конкурентный формат анализа } \\
\hline \multirow{3}{*}{ Левофлоксацин } & 20.0 & $19.5 \pm 6.8$ & 97.5 & 0.08 \\
\hline & 50.0 & $51.8 \pm 7.0$ & 103.6 & 0.05 \\
\hline & 70.0 & $71.1 \pm 8.6$ & 101.6 & 0.03 \\
\hline \multirow{3}{*}{ Ципрофлоксацин } & 20.0 & $19.1 \pm 3.0$ & 95.5 & 0.06 \\
\hline & 50.0 & $51.6 \pm 5.7$ & 103.2 & 0.05 \\
\hline & 70.0 & $70.2 \pm 9.2$ & 100.3 & 0.03 \\
\hline \multicolumn{5}{|c|}{ Прямой формат анализа } \\
\hline \multirow{3}{*}{ Левофлоксацин } & 50.0 & $49.3 \pm 5.5$ & 98.6 & 0.03 \\
\hline & 100 & $99.0 \pm 3.7$ & 99.0 & 0.04 \\
\hline & 300 & $294 \pm 14$ & 98.0 & 0.03 \\
\hline \multirow{3}{*}{ Ципрофлоксацин } & 50.0 & $49.2 \pm 6.9$ & 98.4 & 0.04 \\
\hline & 100 & $98.0 \pm 6.1$ & 98.0 & 0.05 \\
\hline & 300 & $297 \pm 17$ & 99.0 & 0.04 \\
\hline
\end{tabular}

Величины относительного стандартного отклонения $\mathrm{s}_{\mathrm{r}}$ свидетельствуют о высокой воспроизводимости результатов измерений ( $\mathrm{s}_{\mathrm{r}}$ не превышает 0.08$)$.

\section{Заключение}

Разработанные методики позволяют осуществлять чувствительное и селективное (о чем свидетельствуют данные коэффициентов перекрестного взаимодействия, установленные ранее для применяемых антител [21]) определение левофлоксацина и ципрофлоксацина как в конкурентном, так и в прямом форматах анализа. 
Исследования выполнены при финансовой поддержке Министерства образования и науки Российской Федерации, уникальный идентификатор проекта RFMEFI60417X0198.

\section{Список литературы}

1. $\mathrm{Hu} \mathrm{Yu}$, Hui Mun, Ying-Mei $\mathrm{Hu} / / J$. of Pharmaceutical Analysis. 2012. Vol. 2. pp. 7681.

2. Takeda N., Gotoh M., Matsuoka T. // Food Additives and Contaminants. 2011. Vol. 28. No 9. pp. 1168-1174.

3. Patyra E., Kwiatek K. // Analytical Letters. 2017. Vol. 50. pp. 1711-1720.

4. Rodríguez-Díaz R.C., Fernández-Romero J.M., Aguilar-Caballos M.P., Gómez-Hens A. // J. Agric. Food Chem. 2006. Vol. 54. pp. 96709676.

5. Pearce J.N., Burns B.G., Riet J.M., Casey M.D., Potter R.A. // Food Additives and Contaminants. 2009. Vol. 26. pp. 39-46.

6. Шанин И.А., Шаймарданов А.Р., Нгуен Ти Диу Тхай, Еремин С.А. // Журнал аналитической химии. 2015. Т. 70. № 6. С. 617-623.

7. Шанин И.А., Нгуен Ти Диу Тхай, Еремин С.А. // Вестн. Моск. ун-та. 2014. Т. 55. № 3. C.180-186.

8. Chen J., Shanin I.A., Lv S., Wang Q. et al. // J. of the Science of Food and Agriculture. 2015. Vol. 93. pp. 1341-1346.

9. Taranova N.A., Zvereva E.A., Zherdev A.V.,Dzantiev B.B. et al. // Biomedical and Pharmacology Journal. 2015. Vol. 8. No 2. pp. 1389-1398.

10. Jiahong C., Shanin I.A., Shuwei L., Qiang W. et al. // J. of the Science of Food and Agriculture. 2016. Vol. 96. pp. 1341-1346.

\section{References}

1. $\mathrm{Hu} \mathrm{Yu}, \mathrm{Hui}$ Mun, Ying-Mei $\mathrm{Hu}, J$. of Pharmaceutical Analysis, 2012, Vol. 2, pp. 7681; doi: 10.1016/j.jpha.2011.09.007.

2. Takeda N., Gotoh M., Matsuoka T., Food Additives and Contaminants, 2011, Vol. 28, No 9, pp. 1168-1174; doi: 10.1080/19440049 .2011.587028.

3. Patyra E., Kwiatek K., Analytical Letters, 2017, Vol. 50, pp. 1711-1720; doi: 10.1080/00032719.2016.1249876.

4. Rodríguez-Díaz R.C., Fernández-Romero J.M., Aguilar-Caballos M.P., Gómez-Hens A., J. Agric. Food Chem., 2006, Vol. 54, pp. 96709676; doi: 10.1021/jf0621368.
11. Tsekenis G., Garifallou G.Z., Davis F., Millner P.A. et al. // Anal. Chem. 2008. Vol. 80. pp. 9233-9239.

12. Pinachoa D.-G., Gorgy K., Cosnier S., Marco M.-P., Sánchez-Baeza F.J. // IRBM. 2008. Vol. 29. pp.181-186.

13. Giroud F., Gorgy K., Gondran C., Cosnier S. et al. // Anal. Chem. 2009. Vol. 81. pp. 84058409.

14. Karaseva N.A., Ermolaeva T.N. // Talanta. 2012. Vol. 93. pp. 44-48.

15. Мелихова Е.В., Калмыкова Е.Н., Ермолаева Т.Н., Ерёмин С.А. // Журнал аналитической химии. 2006. Т. 61. № 7. С. 744-750.

16. Фарафонова О.В., Шукшина Е.И., Гражулене С.С., Ермолаева Т.Н. // Сорбционные и хроматографические прочессы. 2017. Т.17. № 4. C. 548-356.

17. Шашканова О.Ю., Ермолаева Т.Н. // Заводская лаборатория. Диагностика материалов. 2010. №3. С. 37-41.

18. Гражулене, С. С., Редькин А. Н., Телегин Г. Ф. // Журнал аналитической химии. 2012. Т. 67. № 5. С. 479-484.

19. Ермолаева Т.Н., Дергунова Е.С., Калмыкова Е.Н. Еремин С.А. // Журнал аналитической химии. 2006. Т. 61. № 6. С. 660-665.

20. Ермолаева Т.Н., Калмыкова Е.Н., Шашканова О.Ю. // Российский химический журнал. Т. 52. № 2. С. 17-29.

5. Pearce J.N., Burns B.G., Riet J.M., Casey M.D. et al., Food Additives and Contaminants, 2009, Vol. 26, pp. 39-46; doi: $10.1080 / 02652030802189757$.

6. Shanin I.A., Shaimardanov A.R., Eremin S.A., Thai N.T.D., Zhurnal analiticheskoj himii, 2015, Vol. 70, No 6, pp. 617-623.

7. Shanin I.A., Thai N.T.D., Eremin S.A., Vestnik Moskovskogo Universiteta, 2014, No 3, pp. 180-186.

8. Chen J., Shanin I.A., Lv S., Wang Q., Mao C. et al., J. of the Science of Food and Agriculture, 2015, Vol. 93, pp. 1341-1346; doi: $10.1002 /$ jsfa. 7228 . 
9. Taranova N.A., Zvereva E.A., Zherdev A.V., Dzantiev B.B. et al., Biomedical and Pharmacology Journal, 2015, Vol. 8, No 2, pp. 1389-1398; doi: 10.13005/bpj/899.

10. Jiahong C., Shanin I.A., Shuwei L., Qiang W. et al., J. of the Science of Food and Agriculture, 2016, Vol. 96, No 4, pp. 1341-1346; doi: $10.1002 /$ jsfa. 7228

11. Tsekenis G., Garifallou G.Z., Davis F., Millner P.A. et al., Anal. Chem., 2008, Vol. 80, pp. 9233-9239; doi: 10.1021/ac8014752.

12. Pinachoa D.-G., Gorgy K., Cosnier S., Marco M.-P. et al., IRBM, 2008, Vol. 29, pp.181-186; doi: 10.1016/j.rbmret.2007.11.006.

13. Giroud F., Gorgy K., Gondran C., Cosnier S. et al., Anal. Chem., 2009, Vol. 81, pp. 84058409; doi: 10.1021/ac901290m.

14. Karaseva N.A., Ermolaeva T.N., Talanta, 2012, Vol. 93, pp. 44-48; doi: 10.1016/j.talanta.2011.12.047.

Ермолаева Татьяна Николаевна - профессор кафедры химии, д.х.н., Липецкий государственный технический университет, Липецк

Ерёмин Сергей Александрович - д.х.н., профессор, ведущий научный сотрудник кафедры химической энзимологии, Химический факультет МГУ им. М.В. Ломоносова, Москва

Гражулене Светлана Степановна - главный научный сотрудник, д. х. н., Институт проблем технологии микроэлектроники и особочистых материалов РАН, Черниголовка

Фарафонова Ольга Вячеславовна - доцент кафедры химии, к.х.н., Липецкий государственный технический университет, Липецк

Шукшина Евгения Ивановна - аспирант кафедры химии (специальность «Аналитическая химия»), Липецкий государственный технический университет, Липецк.

Шанин Илья Александрович - аспирант кафедры химической энзимологии (специальность «Биотехнология»), Химический факультет МГУ им. М.В. Ломоносова
15. Melikhova E.V., Kalmykova E.N., Ermolaeva T.N., Eremin S.A., J. of Analytical Chemistry, 2006, Vol. 61, No 7, pp. 687-693.

16. Farafonova O.V., Shukshina E.I., Grazhulene S.S., Ermolaeva T.N., Sorbtsionnye $i$ khromatograficheskie protsessy, 2017, Vol.17, No 4, pp. 548-356.

17. Shashkanova O.Yu., Ermolaeva T.N., Zavodskaja laboratorija. Diagnostika materialov, 2010, No 3, pp. 37-41.

18. Grazhulene S.S., Red'kin A.N., Telegin G.F., Zhurnal analiticheskoj himii, 2012, Vol. 67, No 5, pp. 479-484.

19. Ermolaeva T.N., Dergunova E.S., Kalmykova E.N. Eremin S.A., Zhurnal analiticheskoj himii, 2006, Vol. 61, No 6, pp. 660-665.

20. Ermolaeva T.N., Kalmykova E.N., Shashkanova O.Ju., Rossijskij himicheskij zhurnal, Vol. 52, No 2, pp. 17-29.

Ermolaeva Tatyana N. - prof., grand $\mathrm{Ph} . \mathrm{D}$ (chemistry), department of chemistry, Lipetsk State Technical University, Lipetsk, e-mail: etn@stu.lipetsk.ru

Eremin Sergei A. - prof., grand Ph.D (chemistry), M.V. Lomonosov Moscow State University, e-mail: saeremin@gmail.com

Grazhulene Svetlana S. - chief researcher, grand Ph.D (chemistry), Institute of Microelectronics Technology and High-Purity Materials, Russian Academy of Sciences, Chernigolovka, e-mail: grazhule@impt-hpm.ac.ru

Farafonova Olga V. - associate prof., Ph.D. (chemistry), department of chemistry, Lipetsk State Technical University, Lipetsk, e-mail: farafonova.ov@mail.ru

Shukshina Evgenia I. - postgraduate student, department of chemistry, Lipetsk State Technical University, Lipetsk, e-mail: shukshina evg@mail.ru

Shanin Il'ja A. - postgraduate student, department of chemical enzymology, M.V. Lomonosov Moscow State University, e-mail: numenor08@mail.ru 